\title{
Morphological variation of Philodryas patagoniensis (Girard, 1858) (Serpentes, Dipsadidae) from Brazil, based on the study of pholidosis, coloration and morphometric features
}

\author{
Rafaella Vallim Gouveia ${ }^{I^{*}}$, Iara Alves Novelli', Fabiano Matos Vieira ${ }^{3}$ \& Bernadete Maria de Sousa ${ }^{2}$ \\ ${ }^{1}$ Universidade Federal de Juiz de Fora, Comportamento animal Juiz de Fora, MG, Brazil \\ ${ }^{2}$ Universidade Federal de Juiz de Fora, Departamento de Zoologia, Juiz de Fora, MG, Brazil \\ ${ }^{3}$ Instituto Oswaldo Cruz, Laboratório Helmintos Parasitos de Vertebrados, Rio de Janeiro, RJ, Brazil \\ *Corresponding author: Rafaella Vallim Gouveia, e-mail: rafavallim@gmail.com
}

GOUVEIA, R.V., NOVELLI, I.A., VIEIRA, F.M., SOUSA, B.M. Morphological variation of Philodryas patagoniensis (Girard, 1858) (Serpentes, Dipsadidae) from Brazil, based on the study of pholidosis, coloration and morphometric features. Biota Neotropica. 17(1): e20160237. http://dx.doi.org/10.1590/1676-0611-BN-2016-0237

\begin{abstract}
The current study aimed to verify the relationship between the patterns of coloration, the morphometrical features and pholidosis of specimens of Philodryas patagoniensis from Brazil, with the sexual dimorphism of this species. We studied specimens of P. patagoniensis deposited in several herpetological collections from Brazil. A total of 355 specimens were analyzed, of these 145 were males ( 87 adults and 58 juveniles) and 210 were females (134 adults and 76 juveniles). Adult specimens exhibit sexual dimorphism in snout-vent length, tail length, head length, number of ventral shields, and number of subcaudal shields. The analysis of variance showed that the adult females are significantly longer than adult males, both at snout-vent length and tail length. Females have a greater number of ventral shields (138-210) than males (151-200). The specimens studied also exhibit two distinct patterns of coloration unrelated to geographical or sexual variations.
\end{abstract}

Keywords: Morphology, sexual variability, Philodryadini, Brazilian snakes.

\section{Variação morfológica de Philodryas patagoniensis (Girard, 1858) (Serpentes, Dipsadidae) no Brasil, com base em estudos das características de folidose, coloração e morfometria}

\begin{abstract}
Resumo: O presente estudo objetivou verificar a relação entre os padrões de coloração, as características morfométricas e a folidose de espécimes de Philodryas patagoniensis existentes no Brasil, com o dimorfismo sexual dessa espécie. Foram estudados espécimes de $P$. patagoniensis depositados em várias coleções herpetológicas do Brasil. Um total de 355 espécimes foram analisados, destes 145 eram machos ( 87 adultos e 58 filhotes) e 210 fêmeas ( 134 adultos e 76 filhotes). Espécimes adultos apresentam dimorfismo sexual no comprimento rostro-cloacal, comprimento da cauda, comprimento da cabeça, número de escudos ventrais e número de escudos subcaudais. A análise de variância mostrou que fêmeas adultas são significativamente maiores que machos adultos, tanto no comprimento rostro-cloacal quanto no comprimento da cauda. Fêmeas possuem maior número de escudos ventrais (138-210) que machos (151-200). Os espécimes estudados apresentam dois padrões distintos de coloração não relacionadas a variações geográficas ou sexuais.
\end{abstract}

Palavra-chave: Morfologia, variabilidade sexual, Philodryadini, serpentes Brasileiras.

\section{Introduction}

External morphological features as pholidosis, measures of body regions and patterns of coloration of specimens are fundamental for taxonomic studies of snakes (Thomas 1976, Di-Bernardo \& Lema 1990, López \& Giraudo 2008). Pholidosis is the arrangement or pattern of scales and shields on the body surface of reptiles and is one of features for identification of snakes, and is a feature that may have variations within the same species (Dowling 1951a, b). The differences between the phenotypes such as folidose, morphology and physiology reflect the functional capacity of the specimen, which in turn are adaptive to different environments (Arnold 1983, Greene 1986, Coddington 1988, Emerson \& Arnold 1989, Arnold 1994, Garland \& Losos 1994).
Differences in behavior may influence evolutionary changes, for example, the occurrence of populations or species different from the usual habitat, possibly exhibiting different behaviors, which may lead to selection of phenotypes that maximize the effectiveness of these behaviors and the animal's relationship to its habitat (Mayr 1963).

Research on sexual dimorphism performed in several species of snakes of the families Colubridae and Dipsadidae demonstrate that the females have a highest snout-vent length compared to males (Solorzano \& Cerdas 1989, Rivas \& Burghardt 2001, Zug et al. 2001), and males have a highest tail length than females (King 1989, López \& Giraudo 2008, Matias et al. 2011).

The Patagonia green racer, Philodryas patagoniensis (Girard, 1858) (Dipsadidae), occurs in Argentina, Bolívia, Brazil, Chile, Paraguay 
and Uruguay (Thomas 1976, Peters et al. 1986, López \& Giraudo 2008). This species was described by Girard (1858) as Callirhinus patagoniensis, based on two specimens collected in coastal region of Patagonia, Argentina. These two specimens were described as having mainly an olive-green coloration with black spots, 19 midbody rows of dorsal scales, divided cloacal and subcaudal shields, a divided nasal scale, a pair of loreal scales, two post-ocular scales, and one pre-ocular scale, with the third and fourth supralabial scales in contact with the orbit. This species was included into the genus Philodryas Wagler, 1830 by Hoge (1964), and redescribed by Thomas (1976).

The study of López \& Giraudo (2008) with specimens of P. patagoniensis from Argentina is the only one that reveals significant differences in pholidosis of males and females of this species. Other studies with $P$. patagoniensis have addressed for ecological and natural history approaches (see Thomas 1976, Cei 1993, Achaval \& Olmos 1997, Fowler \& Salomão 1994a, b, 1995, Hartmann \& Marques 2005, López \& Giraudo 2008). Not only in specimens of $P$. patagoniensis, as in the whole tribe Philodryadini, from Brazil the studies with sexual dimorphism associated with pholidosis and morphometric features of this species are still scarce (Fowler \& Salomão 1994a, b, 1995, Pontes 2007, López \& Giraudo 2008, Zaher et al. 2008).

Therefore, the current study aimed to analyze the differences between sexual dimorphism and the patterns of coloration, the morphometrical features and pholidosis of $P$. patagoniensis from Brazil.

\section{Material and methods}

The current study was performed with specimens of $P$. patagoniensis from several locaties in Brazil, and deposited in the following herpetological collections from Brazil: Museu de Zoologia João Moojen (MZUFV), from Universidade Federal de Viçosa, Viçosa; Fundação Ezequiel Dias (FUNED), Belo Horizonte; Museu de Ciências Naturais from Pontifícia Universidade Católica de Minas Gerais (MCNR), Belo Horizonte; Laboratório de Zoologia de Vertebrados from Universidade de Federal de Ouro Preto (LZV), Ouro Preto; Coleção Herpetológica da Universidade de Brasília (CHUNB), Brasília; Universidade Federal de Juiz de Fora (UFJF), Juiz de Fora; Centro Universitário de Lavras (UNILAVRAS), Lavras; Museu Nacional (MNRJ), Rio de Janeiro; and Museu de Zoologia da Universidade de São Paulo (MZUSP), São Paulo.

The specimens were analyzed between May 2011 and September 2012. A total of 355 specimens of Philodryas patagoniensis were analyzed, of which 145 were males ( 87 adult specimens and 58 juveniles) and 210 were females (134 adults and 76 juveniles) (see appendix). The speciemens analyzed in the current study were identified according to morphological diagnostic features proposed by Girard (1858), and Thomas (1976).

The features of pholidosis analyzed or quantified are: number of dorsal scales (NDS), number of ventral shields (NVS), number of subcaudal shields (NSS), supra-labial scales (SLS), pre-ocular scales (PRS), post-ocular scales (POS), supra-ocular scales (SOS), nasal scale (NS), rostral scale (RS), loreal scale (LS), pre-frontal scales (PFS), parietal scales (PS), temporal scales (TS), infra-labial scales (ILS) and cloacal shields (CS), when possible was used the "first wider than long" system. The measurable features analyzed are: head length (HL), head width (WH), inter-ocular width (IOW), snout-vent length (SVL), tail length (TL), and total length (TBL). The measurements were made using analogical calliper and metric rule, according to Dowling (1951b), Thomas (1976), and Francini et al. (1990).

The sexual size dimorphism (SSD) was calculated according to the index adapted from Gibbons \& Lovich (1990): SSD = mean SVL of the larger sex divided by the mean SVL of the smaller sex, where negative values indicate that males are larger than females. Individuals missing all or part of the tail were not used in the analyses that employed SVL and TL values. Females with SVL $<670 \mathrm{~mm}$ and males with $\mathrm{SVL}<525 \mathrm{~mm}$ were classified as juveniles, according to Pontes (2007).
The relationship of sex and/or sexual maturity with the NVS, NSS, SVL, and TL was determined by the Wilcoxon test. The same test was used to relate the HL with the sex of the specimens and to relate the NVS, NSS, SVL, TL, TBL, HL, WH and IOW to the patterns of coloration.

An analysis of covariance (ANCOVA) was used to relate the SVL to the $\mathrm{TL}$; three models were tested: model $1\left(\mathrm{SVL}=\beta_{0}+\beta_{1} \mathrm{Sex}+\beta_{2} \mathrm{TL}+\beta_{3} \mathrm{Sex}: \mathrm{TL}\right)$, $\operatorname{model} 2\left(\mathrm{SVL}=\beta_{0}+\beta_{1} \mathrm{Sex}+\beta_{2} \mathrm{TL}\right)$ and $\operatorname{model} 3\left(\mathrm{SVL}=\beta_{0}+\beta_{1} \mathrm{TL}+\beta_{2} \mathrm{Sex}: \mathrm{TL}\right)$. The same tests were used to relate the SVL with the HL using the following models: model 1 ( $\mathrm{SVL}=\beta_{0}+\beta_{1} \mathrm{Sex}+\beta_{2} \mathrm{HL}+\beta_{3}$ Sex:HL), model 2 $\left(\mathrm{SVL}=\beta_{0}+\beta_{1} \mathrm{Sex}+\beta_{2} \mathrm{HL}\right)$ and model $3\left(\mathrm{SVL}=\beta_{0}+\beta_{1} \mathrm{HL}+\beta_{2} \mathrm{Sex}: \mathrm{HL}\right)$. The proportions between TBL and TL, TBL and HL and NVS and NSS were tested by linear regression.

The data was tested for homogeneity of the variances by the Levene test before other statistical analyses. The significance level in all the tests was $\alpha=0.05$. The statistical analyses were carried out with the $\mathrm{R}$ for Windows program.

To determine the sex, in all specimens analyzed was verified the absence or presence of hemipenis by eversion, or through a small median longitudinal section in the region of the first subcaudal shields according to Yuki (1994).

\section{Results}

In the current study the specimens analyzed exhibited an unmodified rostral-scale, two inter-nasal scales, two prefrontals, a single frontal scale, two parietals, a divided nasal scale, one loreal, one pre-ocular, two post-oculars, one supra-ocular, $1+2$ temporals, 7 or 8 supralabials (with the third and fourth contacting the orbit), 9 or 10 infralabials, 19-19-15 dorsal scale rows with one apical pit, a divided cloacal shield, 138 to 210 ventral shield, and 40 to 123 divided subcaudal shields.

The juvenile and adult females have a higher NVS that than males (Table 1; $\mathrm{W}=3179.5, \mathrm{p}=0.005$ for juveniles; $\mathrm{W}=10062, \mathrm{p}<0.001$ for adults). Adult females have a longer SVL than adult males (Table 1; $\mathrm{W}=10606.5, \mathrm{p}<0.001)$ and the SVL of juvenile snakes does not differ between the sexes (Table $1 ; \mathrm{W}=2390, \mathrm{p}=0.330$ ).

Males have a greater NSS than females, according to the analysis of covariance (Table 1; $\mathrm{W}=748, \mathrm{p}=0.001$ for juveniles; $\mathrm{W}=1923.5$, $\mathrm{p}=0.001$ for adults), however the adult females have a greater TL than males (Figure 1) (Table 1; $\mathrm{W}=6995, \mathrm{p}=0.007$ ). The TL of the juvenile specimens did not present a statistical difference between the sexes (Figure 1) (Table 1; $\mathrm{W}=1981.5, \mathrm{p}=0.381$ ).

The sexual size dimorphism (SSD) index in P. patagoniensis was positive in this study, confirming that females are larger than males (1.004).

The analysis of covariance between the TL and SVL of males and females $\left(\mathrm{R}^{2}=0.7848 ; \mathrm{F}=638.3\right)$ shows that the TL is influenced both by SVL and by sex, with a good approximation between the sexes based on the TL and SVL values (Figure 1).

The HL of the females $(\mathrm{n}=208)$ ranged between 11.3 to $44.2 \mathrm{~mm}$, while for the males $(n=144)$ it ranged between 7.7 to $33.1 \mathrm{~mm}$. The HL of the females was significantly greater that than HL of males $(\mathrm{W}=20925$, $\mathrm{p}=0.001)$.

Three models were also tested in the analysis of covariance between the HL and SVL of males and females. Model 3 presented the highest significance $\left(\mathrm{R}^{2}=0.8867 ; \mathrm{F}=2740\right)$, with the following coefficients (Intercept: $-280.7827, p=<0.001$; HL: 38.6754, $p=<0.001$ ). Therefore, the head length is closely related to the snout-vent length of the specimens, however, there was no influence of sex in any of the models (Figure 1).

According to the $\mathrm{R}^{2}$ value $\left(\mathrm{R}^{2}=0.006\right)$ found in the regression analysis, there was no correlation between the variables NVS, NSS, and TBL, indicating that these variables are not closely related.

The regression analysis also showed that the TL of these specimens corresponds to $24 \%\left(\mathrm{R}^{2}=0.840\right)$ of the TBL. This means that the TL value 
Morphological variation of $P$. patagoniensis

Table 1. Variation of morphometric and pholidosis characteristics measures separated by sex and age range in the specimens of the Philodryas patagoniensis.

\begin{tabular}{|c|c|c|c|c|c|c|c|c|}
\hline \multirow{2}{*}{ Morphometric } & \multicolumn{4}{|c|}{ Females } & \multicolumn{4}{|c|}{ Males } \\
\hline & $\mathbf{N}$ & Means (cm) & SD & Variation $(\mathrm{cm})$ & $\mathbf{N}$ & Means (cm) & SD & Variation $(\mathrm{cm})$ \\
\hline \multicolumn{9}{|l|}{ Juveniles } \\
\hline Ventral & 75 & 185.21 & 12.69 & $147-207$ & 58 & 177.53 & 7.82 & $155-194$ \\
\hline Subcaudal & 74 & 97.62 & 12.60 & $40-117$ & 56 & 108.38 & 7.94 & $73-119$ \\
\hline SVL & 75 & 349.03 & 137.48 & $144-669$ & 58 & 325.10 & 107.94 & $177-517$ \\
\hline $\mathrm{TL}$ & 75 & 129.35 & 71.06 & $57-439$ & 58 & 128.60 & 51.26 & $66-241$ \\
\hline \multicolumn{9}{|l|}{ Adults } \\
\hline Ventral & 134 & 188.28 & 8.65 & $138-210$ & 86 & 178.06 & 6.7 & $157-196$ \\
\hline Subcaudal & 131 & 94.97 & 12.08 & $40-116$ & 85 & 106.13 & 9.24 & $66-123$ \\
\hline SVL & 134 & 923.81 & 149.1 & $679-1345$ & 86 & 688.38 & 97.2 & $539-1010$ \\
\hline TL & 134 & 298.43 & 56.24 & $90-429$ & 86 & 285.84 & 42.43 & $181-396$ \\
\hline
\end{tabular}

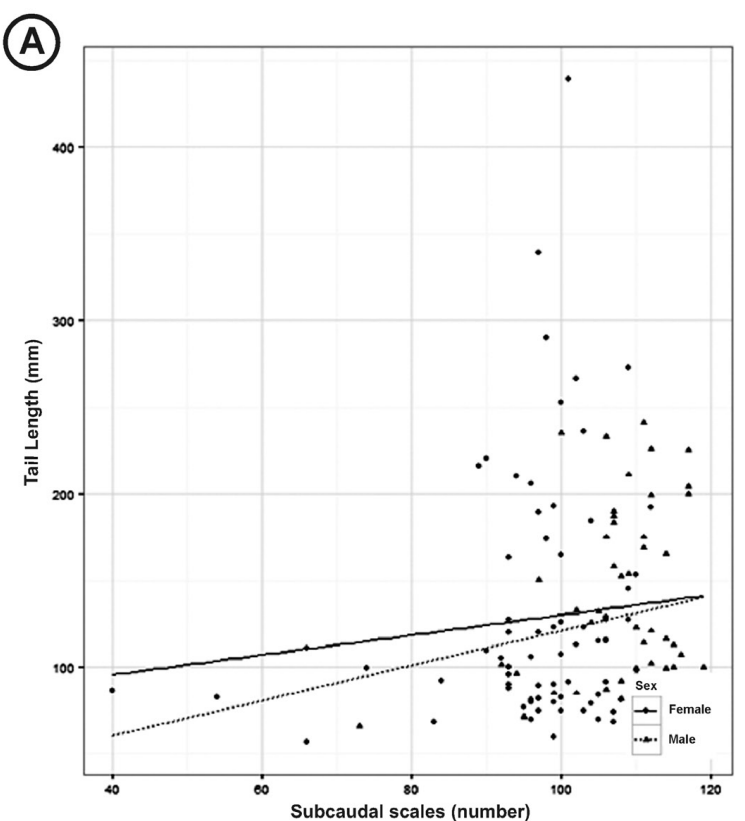

(C)

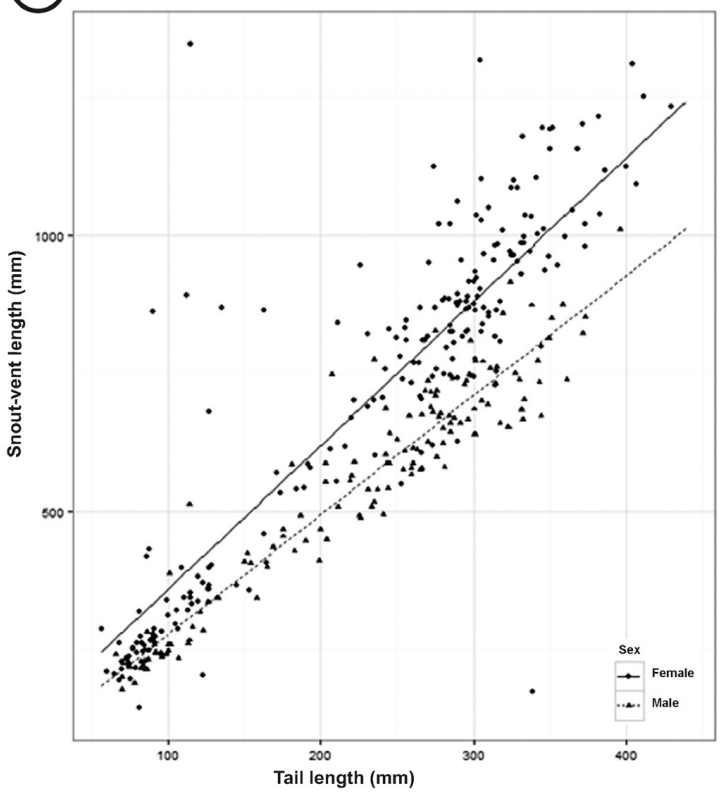

(B)

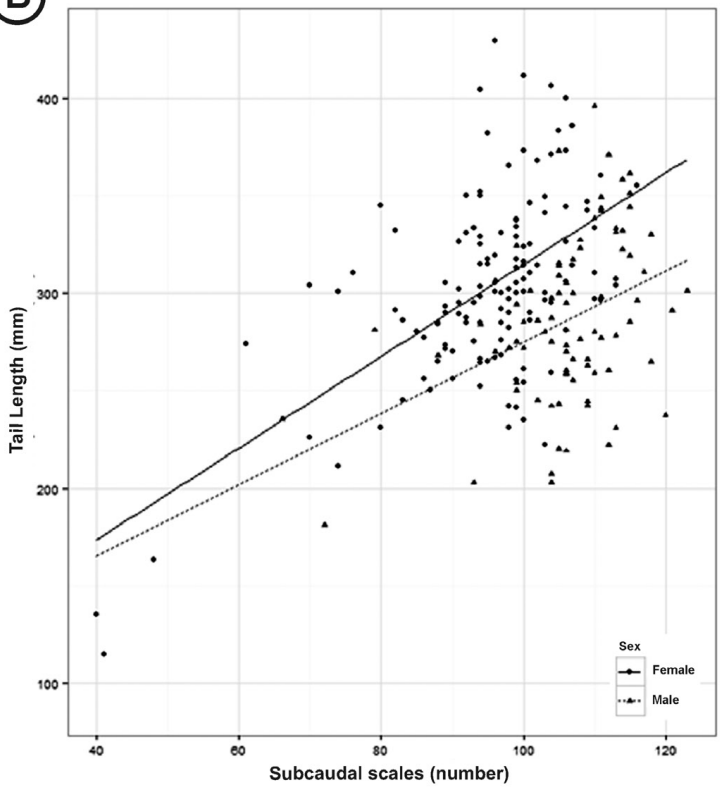

(D)

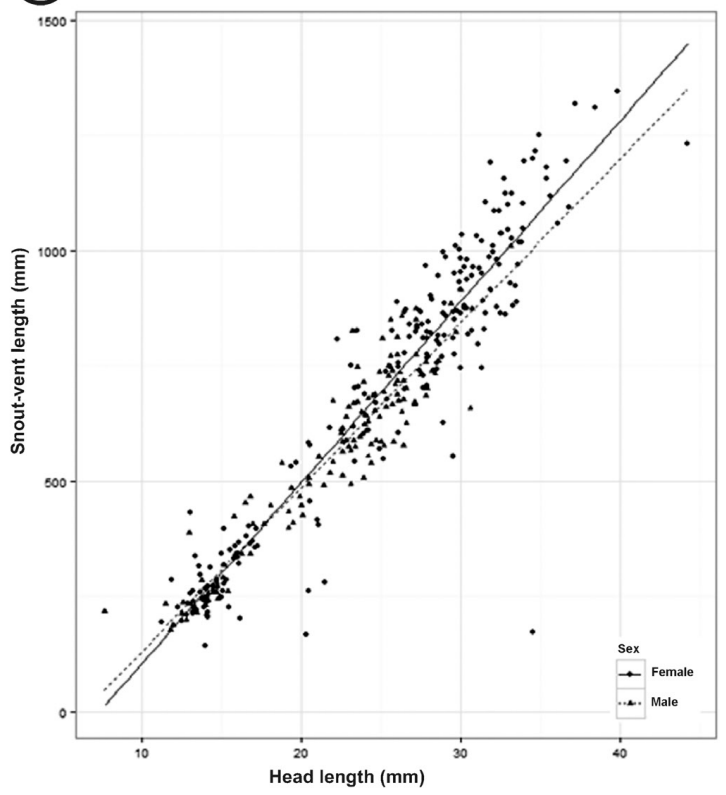

Figure 1. (A) Relation between the tail length and number of subcaudal shield of juveniles females and males. (B) Relation between the tail length and number of subcaudal shield of adults females and males. (C) Relation between the tail length and snout-vent length of females and males. (D) Relationship of the snout-vent length, head length and sex of the specimens. 
can be predicted from the TBL value. The head length is corresponds to $1.8 \%\left(\mathrm{R}^{2}=0.903\right)$ of the TBL. Thus it is possible to obtain any value of TBL or HL from the other pair.

We observed two patterns of coloration in the specimens studied herein: (1) dorsum dark brown, with black spots only on the posterior region of the scales, a clear and delineated black belly, and orange coloration on the head, and (2) uniform brown head and dorsum, light greenish-brown without black spots on the posterior portion of the dorsal scales, a light belly. These patterns (with or without spots) were used for comparisons of the all specimens studied herein (Figure 2) (Table 2).

The correlations of these two patterns of coloration between the NVS, NSS, TBL, SVL, TL, WH, HL, and IOW were performed according to the Wilcoxon test. We observed that only the NVS and NSS variables were not significant. Among the variables that showed significant results, only the variable IOW showed higher mean for the patterns of coloration 2 . For all other variables, the mean was higher for the patterns of coloration 1 (Table 3).

\section{Discussion}

The wide range observed in the NVS and NSS in the specimens studied herein was also observed by Thomas (1976) and D'Agostini (1998) in other species of the genus Philodryas, such as P. aestiva (Duméril, Bibron \& Duméril, 1854), P. olfersii (Lichtenstein, 1823) and P. viridissima (Linnaeus, 1758). Thomas (1976) studied $P$. patagoniensis also found a large variation in the NVS and NSS (151 to 194 ventral shields and 68 to 120 subcaudal shields) than that observed in the current study.

The results obtained on the NSS and NVS of the adults of $P$. patagoniensis are in accordance with observed by López \& Giraudo (2008) in the same species from Argentina. These authors observed that the adult males of $P$. patagoniensis have a higher NSS than the adult females, while the adult females have a higher NVS than the adult males. The higher body size and NVS in females of this species can be a reflective of the optimization of reproductive potential, since the females needs a higher body volume to produce a higher number of eggs or large size of eggs (Mebert 2011).
In the current study we observed a significant difference in the NSS between males and females (Table 1).

We observed that the adult females of $P$. patagoniensis have a largest body size that than adult males (Table 1). A similar pattern of females were reported in several other species of snakes (Solorzano \& Cerdas 1989, Shine 1993, Rivas \& Burghardt 2001, Gregory 2004, Pinto \& Fernandes 2004, Matias et al. 2011, Mesquita et al. 2011, Henao-Duque \& Ceballos 2013).

Several authors observed that the fertility is considered one of the main selective agents for the larger size of females for some species of snakes; however, the largest size of males in another species of snakes can be considered as a significant feature of males of species that possesses the behaviour of competition for territory and for females in reproductive period (Shine 1978, 1993, 1994, 2000, Zug et al. 2001, Matias et al. 2011, Henao-Duque \& Ceballos 2013).

We found a high value of sexual size dimorphism index (SSD), which can possibly indicate the absence of territorial behaviour in P. patagoniensis, since the species of snakes that exhibiting the behaviour of territorial and reproductive dispute usually have $\mathrm{SSD}<0.05$ or with negative values of this index, according Shine $(1978,1994)$ and Oliveira (2008). The same applies to the species $P$. agassizii and $P$. nattereri, since they have SSD $>0.05$ and there are no indications of territorial behavior (Marques et al. 2006, Mesquita et al. 2011).

Shine (1978) says that the late maturity in female snakes can represent a trade off in which the sexual maturity is delayed until their body size allows the production of sufficiently numerous and large eggs, and highest fertility. Sex differences in snake body size adjustments are considered that may lead to a higher success reproductive (Pizzatto et al. 2007). Therefore, the sexual dimorphism probably exists due to the benefits of larger body size of female so that, according to Pizzatto et al. (2007), the natural selection has favored females with larger body size. Studies of snakes have shown that on the average females are larger than males (approximately 15\%) in species where males do not compete for mates, Shine (1994). The sexual dimorphism occurring in the SVL of $P$. patagoniensis indicates than the sexes reach maturity at different sizes; however, according to Fowler \& Salomão (1995) it is known that growth is not a continuous process.

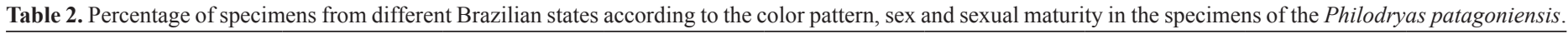

\begin{tabular}{|c|c|c|c|c|c|c|c|c|}
\hline \multirow{3}{*}{ Localities } & \multicolumn{4}{|c|}{ Female } & \multicolumn{4}{|c|}{ Males } \\
\hline & \multicolumn{2}{|c|}{ Juveniles } & \multicolumn{2}{|c|}{ Adults } & \multicolumn{2}{|c|}{ Juveniles } & \multicolumn{2}{|c|}{ Adults } \\
\hline & Pattern 1 & Pattern 2 & Pattern 1 & Pattern 2 & Pattern 1 & Pattern 2 & Pattern 1 & Pattern 2 \\
\hline Bahia & $0 \%$ & $0 \%$ & $2 \%$ & $0 \%$ & $0 \%$ & $3 \%$ & $10 \%$ & $8 \%$ \\
\hline Distrito Federal & $20 \%$ & $23 \%$ & $10 \%$ & $15 \%$ & $16 \%$ & $0 \%$ & $0 \%$ & $17 \%$ \\
\hline Espírito Santo & $0 \%$ & $0 \%$ & $4 \%$ & $0 \%$ & $0 \%$ & $0 \%$ & $0 \%$ & $0 \%$ \\
\hline Goiás & $7 \%$ & $0 \%$ & $5 \%$ & $9 \%$ & $2 \%$ & $18 \%$ & $6 \%$ & $8 \%$ \\
\hline Maranhão & $0 \%$ & $0 \%$ & $0 \%$ & $0 \%$ & $0 \%$ & $0 \%$ & $4 \%$ & $0 \%$ \\
\hline Mato Grosso & $0 \%$ & $0 \%$ & $0 \%$ & $0 \%$ & $0 \%$ & $0 \%$ & $4 \%$ & $0 \%$ \\
\hline Mato Grosso do Sul & $0 \%$ & $0 \%$ & $3 \%$ & $0 \%$ & $0 \%$ & $0 \%$ & $0 \%$ & $0 \%$ \\
\hline Minas Gerais & $35 \%$ & $38 \%$ & $30 \%$ & $30 \%$ & $49 \%$ & $29 \%$ & $33 \%$ & $34 \%$ \\
\hline Pará & $0 \%$ & $0 \%$ & $1 \%$ & $0 \%$ & $0 \%$ & $0 \%$ & $0 \%$ & $0 \%$ \\
\hline Paraíba & $0 \%$ & $0 \%$ & $0 \%$ & $3 \%$ & $2 \%$ & $13 \%$ & $0 \%$ & $0 \%$ \\
\hline Paraná & $0 \%$ & $0 \%$ & $1 \%$ & $3 \%$ & $2 \%$ & $6 \%$ & $0 \%$ & $0 \%$ \\
\hline Pernambuco & $0 \%$ & $0 \%$ & $0 \%$ & $0 \%$ & $0 \%$ & $6 \%$ & $0 \%$ & $0 \%$ \\
\hline Rio de Janeiro & $17 \%$ & $15 \%$ & $16 \%$ & $9 \%$ & $10 \%$ & $3 \%$ & $16 \%$ & $8 \%$ \\
\hline Rio Grande do Sul & $2 \%$ & $8 \%$ & $5 \%$ & $3 \%$ & $4 \%$ & $0 \%$ & $0 \%$ & $0 \%$ \\
\hline Roraima & $0 \%$ & $0 \%$ & $0 \%$ & $0 \%$ & $0 \%$ & $0 \%$ & $0 \%$ & $0 \%$ \\
\hline Santa Catarina & $4 \%$ & $0 \%$ & $1 \%$ & $0 \%$ & $4 \%$ & $0 \%$ & $0 \%$ & $1 \%$ \\
\hline São Paulo & $9 \%$ & $8 \%$ & $20 \%$ & $9 \%$ & $7 \%$ & $23 \%$ & $23 \%$ & $17 \%$ \\
\hline Sergipe & $4 \%$ & $0 \%$ & $0 \%$ & $6 \%$ & $0 \%$ & $3 \%$ & $0 \%$ & $0 \%$ \\
\hline Tocantins & $2 \%$ & $8 \%$ & $2 \%$ & $13 \%$ & $4 \%$ & $6 \%$ & $4 \%$ & $0 \%$ \\
\hline
\end{tabular}




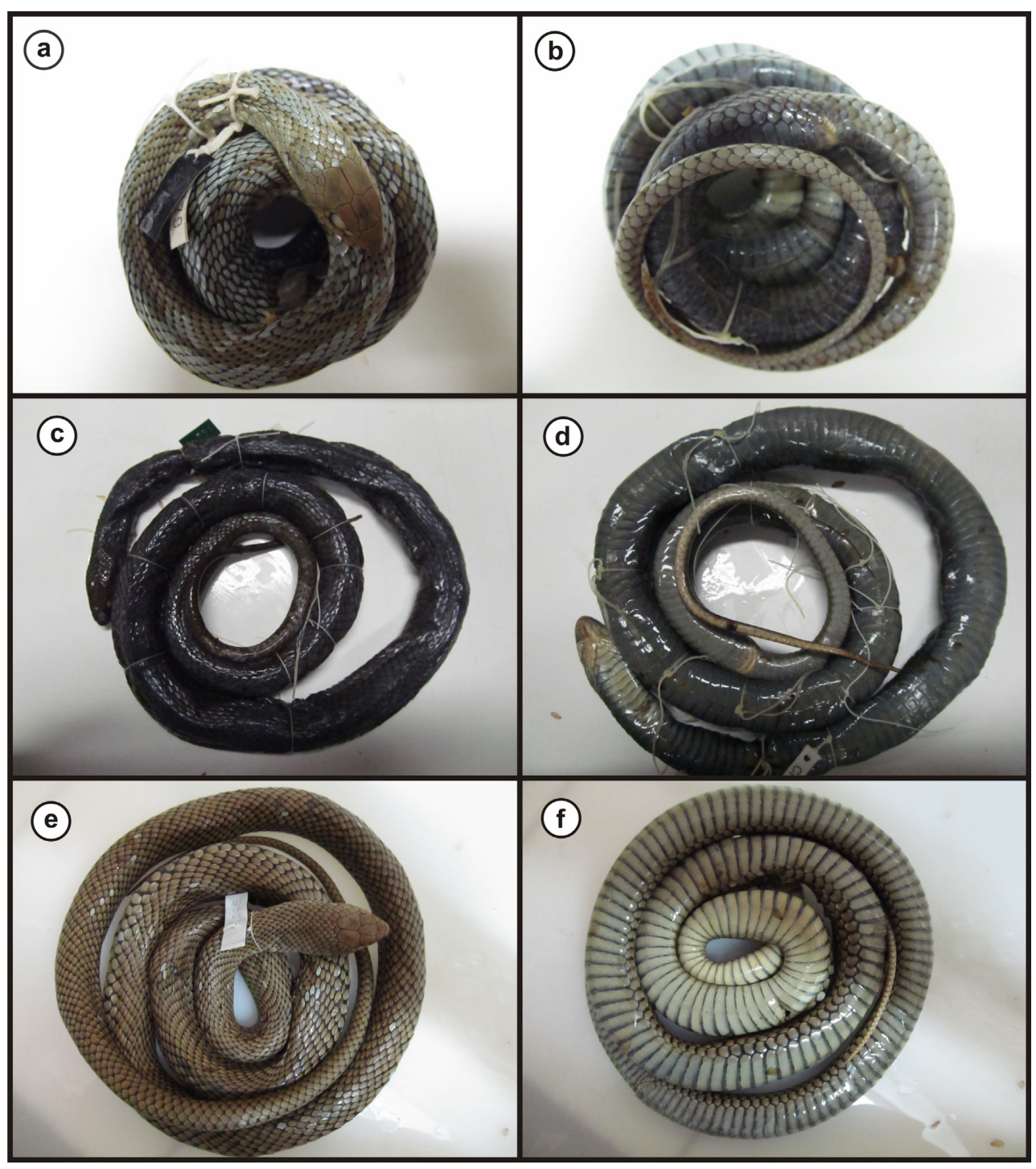

Figure 2. (A) Pattern of coloration 1 of specimen of Philodryas patagoniensis deposited in the Herpetological Collection of Universidade de Brasília (CHUNB), dorsal view. (CHUNB 3779, Brasília - DF). (B) Pattern of coloration 1 of specimen of Philodryas patagoniensis deposited in the Herpetological Collection of Universidade de Brasília (CHUNB), ventral view. (CHUNB 3779, Brasília - DF). (C) Pattern of coloration 2 of specimen of Philodryas patagoniensis deposited in the Herpetological Collection of Universidade de Brasília (CHUNB), dorsal view. (CHUNB 19337, Brasília - DF). (D) Pattern of coloration 2 of specimen of Philodryas patagoniensis deposited in the Herpetological Collection of Universidade de Brasília (CHUNB), ventral view. (CHUNB 19337, Brasília - DF). (E) Pattern of coloration 1 of specimen of Philodryas patagoniensis deposited in the Herpetological Collection of Museu de Zoologia João Moojen of Universidade Federal de Viçosa (MZUFV), dorsal view. (MZUFV 1369, Tocantins - MG). (F) Pattern of coloration 1 of specimen of Philodryas patagoniensis deposited in the Herpetological Collection of Museu de Zoologia João Moojen of Universidade Federal de Viçosa (MZUFV), ventral view. (MZUFV 1369, Tocantins - MG).

Table 3. Total number, means, standard deviation, variation and statistical results between the coloration patterns with variable: number of ventral and subcaudal shields (NVS and NSS), total length (TBL), snout-vent length (SVL), tail length (TL), head length (HL), head width (WH) and inter-ocular width (IOW) of Philodryas patagoniensis. Statistical significance represented by $*$ in the table.

\begin{tabular}{|c|c|c|c|c|c|c|c|c|c|}
\hline \multirow{3}{*}{ Scales } & \multicolumn{8}{|c|}{ Patterns of coloration } & \multirow{3}{*}{$\begin{array}{c}\text { Test Wilcoxon } \\
\text { p-value }\end{array}$} \\
\hline & \multicolumn{4}{|c|}{ Parttens 1} & \multicolumn{4}{|c|}{ Parttens 2} & \\
\hline & $\mathbf{N}$ & $\begin{array}{l}\text { Means } \\
(\mathrm{cm})\end{array}$ & SD & $\begin{array}{l}\text { Variation } \\
\text { (cm) }\end{array}$ & $\mathbf{N}$ & $\begin{array}{l}\text { Means } \\
(\mathrm{cm})\end{array}$ & SD & $\begin{array}{l}\text { Variation } \\
\text { (cm) }\end{array}$ & \\
\hline NVS & 256 & 183.73 & 9.81 & $138-210$ & 95 & 183.05 & 10.65 & $154-207$ & $\mathrm{~W}=12893.5, \mathrm{p}<0.385$ \\
\hline NSS & 251 & 100.25 & 11.45 & $40-123$ & 93 & 102.12 & 11.95 & $41-120$ & $\mathrm{~W}=10205.5, \mathrm{p}<0.073$ \\
\hline TBL & 256 & 907.12 & 397.57 & $247-1713$ & 95 & 807.21 & 284.64 & $225-1460$ & $\mathrm{~W}=14612, \mathrm{p}<0.004^{*}$ \\
\hline SVL & 256 & 670.09 & 304.86 & $168-1317$ & 95 & 587.38 & 219.36 & $144-1345.4$ & $\mathrm{~W}=14566, \mathrm{p}<0.004^{*}$ \\
\hline TL & 256 & 237,03 & 103.03 & $60-439$ & 95 & 219.83 & 78.35 & $57-360$ & $\mathrm{~W}=14251, \mathrm{p}<0.013^{*}$ \\
\hline HL & 256 & 24.45 & 7.37 & $11-44.2$ & 94 & 22.62 & 5.64 & $7.7-39.8$ & $\mathrm{~W}=14320, \mathrm{p}<=0.006^{*}$ \\
\hline WH & 256 & 10.03 & 3.59 & $3.3-29.6$ & 95 & 9.5 & 3.44 & $4.4-32.8$ & $\mathrm{~W}=13854, \mathrm{p}<0.045^{*}$ \\
\hline IOW & 256 & 7.98 & 2.41 & $2.2-21.1$ & 95 & 8.24 & 7.79 & $3.1-81.3$ & $\mathrm{~W}=14000.5, \mathrm{p}<0.019^{*}$ \\
\hline
\end{tabular}


According to Mesquita et al. (2010), in specimens of Oxybelis aeneus (Wagler in Spix, 1824) (Colubridae) from Brazil the growth rate declines after sexual maturity and therefore females reach maturity at a larger average size than males; although adult males with larger tails that adult females are most commonly pattern found in snakes, due to the presence of hemipenis and retractors muscles (Shine 1993). However, we observed that this pattern of tail sizes of males and females in $P$. patagoniensis (Table 1) not correspond with reported in most species of snakes. We can not find arguments that could support a hypothesis about females having a larger tail than males. Perhaps in the future, with the increase of studies on morphometric patterns in other species of neotropical snakes, not yet studied, could elucidate this fact. López \& Giraudo (2008) found out that there is difference in the count and size of the shields of females and adults males of $P$. patagoniensis. Females have more ventral shields and males have more subcaudal shields. Vanzolini \& Brandão $(1944,1945)$ found the occurrence of that dimorphism in Bothrops alternatus Duméril, Bibron \& Duméril, 1854, with the same pattern (females have a higher number of dorsal scales and ventral shields, and males have a higher number of subcaudal shields), however, as in the current study these authors also do not find a justification that would explain this fact.

Although sexual dimorphism in HL is related to dietary differences as suggested by Pough \& Groves (1983), Forsman (1991), Shine (1986, 1991), Houston and Shine (1993), Forsman (1996), King (2002), Shetty
\& Shine (2002), Nogueira et al. (2003), Aubret et al. (2004), Vincent et al. (2004), and López et al. (2013). The differences found in HL between males and females of $P$. patagoniensis are not related to diet (Hartmann \& Marques 2005, López \& Giraudo 2008). This result is consistent with the observations of Mesquita et al. (2011) for the species P. nattereri, indicating that the sexual dimorphism observed is due to reproductive characteristics (Luiselli et al. 2002).

The sexual dimorphism can be observed in different ways in snakes (Rivas \& Burghardt 2001). For several species the sexual dimorphism is related to volume and size of body (Shine 1993, 1994); the shape and size of head is another feature for diagnostic of sexual dimorphism (Camilleri \& Shine 1990, Vincent et al. 2004); the size of visceral mass and glands also is a important feature for detection of sexual dimorphism (Kissner et al. 1998); but some authors affirms that the patterns of coloration rarely is related to sexual dimorphism (Shine 1993, Marques \& Sazima 2003). In the current study we can affirm that not exist a significant difference in the pattern of coloration between males and females of $P$. patagoniensis.

The specimens that we examined from the state of Roraima have not been reported previously in the literature; therefore the current study provides data that expands geographic distribution of this species in Brazil (Figure 3).

We can affirm that the specimens of $P$. patagoniensis studied herein had a great variation in the folidosis. Sexual dimorphism in relation to

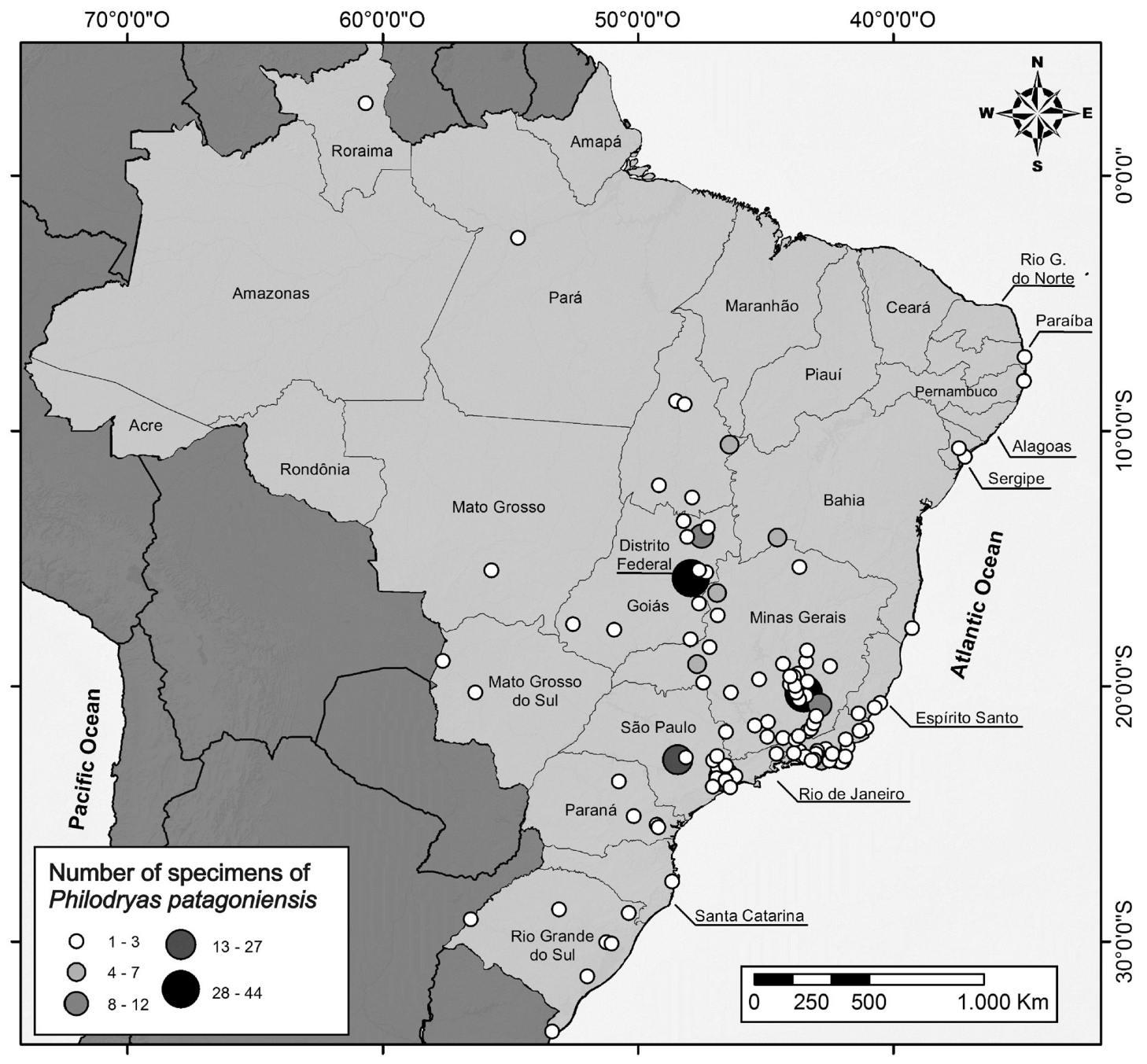

Figure 3. Distribution of studied specimens of Philodryas patagoniensis in 18 states of Brazil and the Federal District. 
SVL, TL, NVS, NSS, and HL was observed. Adult females are larger than adult males in SVL and TL. However, in juveniles these differences do not occur. Females have a greater number of ventral shields than males, and males have a greater number of subcaudal shields. Also we can affirm that the specimens of $P$. patagoniensis studied have two distinct patterns of coloration, however without geographic and sexual specificity for these patterns.

\section{Acknowledgments}

Gouveia, R.V. was supported by a Master Student fellowship from Coordenação de Aperfeiçoamento de Pessoal de Nível Superior (CAPES). Novelli, I.A. was supported by a Postdoctoral fellowship from Programa Nacional de Pós-doutorado (PNPD) CAPES/UFJF at the Programa de Pós Gradução em Ciências Biológicas, Comportamento e Biologia Animal, UFJF. Vieira, F.M. was supported by a Postdoctoral fellowship from Programa Nacional de Pós-doutorado (PNPD) CAPES/FIOCRUZ (Fundação Instituto Oswaldo Cruz) at the Programa de Pós-graduação em Biodiversidade e Saúde (PPGBS) of the Instituto Oswaldo Cruz (IOC), Rio de Janeiro, RJ. Sousa, B.M. was supported by Productivity fellowship by Conselho Nacional de Desenvolvimento Científico e Tecnológico (CNPq). We wish to thank the curators of the Zoological Collections of FUNED-MG, MCNR-MG, CHUNB-DF, LZV-MG, MNRJ-RJ, MUSUSP-SP and MZUFV-MG for allowing access to specimens deposited at these collections.

\section{References}

ACHAVAL, F. \& OLMOS, A. 1997. Anfíbios y Reptiles del Uruguay. Barreiro y Ramos S.A., Montevideo.

ARNOLD, S.J. 1983. Morphology, performance and fitness. Am. Zool. 23(1983): 347-361.

ARNOLD, S.J. 1994. Constraints on phenotypic evolution. In: Behavioral Mechanisms in Evolutionary Biology (L.A. REAL, ed.). University of Chicago Press, Chicago, p.258-278.

AUBRET, F., BONNET, X., MAUMELAT, S., BRADSHAW, D. \& SCHWANER, T. 2004. Diet divergence, jaw size and scale counts in two neighbouring populations of Tiger Snakes (Notechis scutatus). Amphibia-Reptilia 25(2004): 9-17.

CAMILLERI, C. \& SHINE, R. 1990. Sexual dimorphism and dietary divergence: differences in trophic morphology between male and female snakes. Copeia 1990(3): 658-665.

CEI, J.M. 1993. Reptiles del noroeste, nordeste y este de Argentina. Herpetofauna de las Selvas Subtropicales, Puna y Pampas. Monograph, Museo Regionale di Scienze Naturali Bollettino, Torino.

CODDINGTON, J.A. 1988. Cladistic tests of adaptational hypotheses. Cladistics 4(1988):1-20.

D'AGOSTINI, F.M. 1998. Variação da folidose de Philodryas aestivus (Duméril, Bibron \& Duméril, 1854) e a invalidação das subespécies (Serpentes, Colubridae, Xenodontinae, Philodryadini). Biociências 6(1): 169-182.

DI-BERNARDO, M. \& LEMA, T. 1990. O gênero Rhadinaea Cope, 1863 no Brasil meridional. IV - Rhadinaea bilineata (Fischer, 1885) (Serpentes, Colubridae). Acta Biol. Leopoldensia 12(2): 359-392.

DOWLING, H.G. 1951a. A proposal method of expressing scale reduction in snakes. Copeia 1951(2): 131-134

DOWLING, H.G. 1951b. A proposed standard system of counting ventrals in snakes. Br. J. Herpetol. 1(1): 97-99.

EMERSON, S.B. \& ARNOLD, S.J. 1989. Intra- and interspecific relationships between morphology, performance, and fitness. In Complex Organismal Functions: Integration and Evolution in Vertebrates (D.B. WAKE \& G. ROTH, eds.). Wiley, NewYork, p. 295-314.

FORSMAN, A. 1991. Adaptive variation in head size in Vipera berus L. populations. Biol. J.Linn. Soc. 43(4): 281-296.

FORSMAN, A. 1996. An experimental test for food effects on head size allometry in juvenile snakes. Evolution 50(6): 2536-2542.
FOWLER, I.R. \& SALOMÃO, M.G. 1994a. Activity patterns in the colubrid genus Philodryas and their relationship to reproduction and snakebite. Bull. Chicago Herp. Soc. 29(10): 229-232.

FOWLER, I.R. \& SALOMÃO, M.G. 1994b. A study of sexual dimorphism in six species of the colubrid snakes genus Philodryas. Snake 26(1): 117-122.

FOWLER, I.R. \& SALOMÃO, M.G. 1995. A new technique to distinguish between immature and adult snakes and between males and females in six species of the Neotropical colubrid Philodryas. Stud. Neotrop. Fauna E. 30(3): 149-157.

FRANCINI, F., PELUSO, F.O. \& GRISOLIA, C.S. 1990. Método para la identificación individual de Bothrops alternatus Duméril, Bibron \& Duméril, 1854 (Ophidia, Viperidae) en laboratorio. Mem. Inst. Butantan 52(1): 25-31.

GARLAND Jr, T. \& LOSOS, J.B. 1994. Ecological morphology of locomotor performance in squamate reptiles. In Ecological Morphology-Integrative organismal biology (P.C. WAINWRIGHT, \& S.M. REILLY, eds.). University of Chicago Press, Chicago, p.240-302.

GIBBONS, J.W. \& LOVICH, J.E. 1990. Sexual dimorphism in turtles with emphasis on the slider turtle (Trachemys scripta). Herp. Monog. 4(1990): 1-29.

GIRARD, C. 1858. Descriptions of some new Reptiles, collected by the US. Exploring Expedition under the command of Capt. Charles Wilkes, U.S.N. Third Part. Proc. Acad. Nat. Sci. Philadelphia 9(6): 181-182.

GREENE, H.W. 1986. Natural history and evolutionary biology. In PredatorPrey Relationships: Perspectives and Approaches from the Study of Lower Vertebrates (M.E. FEDER \& G.V. LAUDER, eds.). University of Chicago Press, Chicago, p.99-108.

GREGORY, P.T. 2004. Sexual dimorphism and allometric size variation in a population of Grass Snakes (Natrix natrix) in southern England. J. Herpetol. 38(1): $231-240$

HARTMANN, P.A. \& MARQUES, O.A.V. 2005. Diet and habitat use of two sympatric species of Philodryas (Colubridae), in south Brazil. AmphibiaReptilia 26(2005):25-31.

HENAO-DUQUE, A.M. \& CEBALLOS, C.P. 2013. Sex-related head size and shape dimorphism in Mapaná snakes (Bothrops asper) kept in captivity. Rev. Colomb. Cienc. Pecu. 26(3): 201-210.

HOGE, A.R. 1964. Notes Sur Xenodon schottii Schlegel Serpentes. Mem. Inst. Butantan 30(1): 65-70.

HOUSTON, D. \& SHINE, R. 1993. Sexual dimorphism and niche divergence: feeding habits of the Arafura filesnake. J. Anim. Ecol. 62(4): 737-748.

KING, R.B. 1989. Sexual dimorphism in snake tail length: sexual selection, natural selection, or morphological constraint? Biol. J. Linn. Soc. 38(2): 133-154.

KING, R.B. 2002. Predicted and observed maximum prey size-snake size allometry. Funct. Ecol. 16(1): 766-772.

KISSNER, K.J., FORBES, M.R. \& SECOY, D.M. 1998. Sexual dimorphism in size of cloacal glands of garter snake, Thamnophis radix haydeni. J. Herpetol., 32(2): 268-270

LÓPEZ, M.S. \& GIRAUDO, A.R. 2008. Ecology of the Snake Philodryas patagoniensis (Serpentes, Colubridae) from Northeast Argentina. J. Herpetol. 42(3): 474-480.

LÓPEZ, M.S., MANZANO, A.S. \& PRIETO, Y.A. 2013. Ontogenetic Variation in Head Morphology and Diet in Two Snakes (Viperidae) from Northeastern Argentina. J. Herpetol. 47(3): 406-412.

LUISELLI, L., AKANI, G.C. \& ANGELICI, F.M. 2002. Comparative feeding strategies and dietary plasticity of the sympatric cobras Naja melanoleuca and Naja nigricollis in three diverging Afrotropical habitats. Can. J. Zool. 80(1): 55-63.

MARQUES, O.A.V. \& SAZIMA, I. 2003. Ontogenetic colour changes may strengthen suggestion about systematic affinities between two species of Chironius (Serpentes: Colubridae). Phyllomedusa 2(1): 65-67.

MARQUES, O.A.V., SAWAYA, R.J., STENDER-OLIVEIRA, F. \& FRANÇA, F.G.R. 2006. Ecology of the colubrid snake Pseudablabes agassizzi in Southeastern South America. J. Herpetol. 16(1): 37-45.

MATIAS, N.R., ALVES, M.L.M., ARAUJO, M.L. \& JUNG, D.M.H. 2011. Variação morfométrica em Bothropoides jararaca (Serpentes, Viperidae) no Rio Grande do Sul. Iheringia Sér. Zool. 101(4): 275-282.

MAYR, E. 1963. Animal Species and Evolution. 1 ed. Harvard University Press, Cambridge.

MEBERT, K. 2011. Geographic variation of morphological characters in the dice snake (Natrix tessellata). Mertensiella 18(1): 11-20. 
MESQUITA, P.C.M.D., BORGES-NOJOSA, D.M. \& BEZERRA, C.H. 2010 Dimorfismo sexual na "cobra-cipó" Oxybelis aeneus (Serpentes, Colubridae) no estado do Ceará, Brasil. Biotemas 23(4): 65-69.

MESQUITA, P.C.M.D., BORGES-NOJOSA, D.M., PASSOS, D.C. \& BEZERRA, C.H. 2011. Ecology of Philodryas nattereri in the Brazilian semi-arid region. Br. J. Herpetol. 2011(21): 193-198.

NOGUEIRA, C., SAWAYA, R.J. \& MARTINS, M. 2003. Ecology of the Pitviper, Bothrops moojeni, in the Brazilian Cerrado. J. Herpetol. 37(4): 653-659.

OLIVEIRA, F.S. 2008. Ecologia alimentar e reprodutiva de duas espécies de Tropidodryas (Serpentes, Colubridae) da Mata Atlântica. Dissertação de mestrado, Universidade de São Paulo, São Paulo.

PETERS, A.J., DONOSO-BARROS, R. \& OREJAS-MIRANDA, B. 1986. Catalogue of Neotropical Squamata Part I: Snakes. 1 ed. Smithsonian Institute Press, London.

PINTO, R.R. \& FERNANDES, R. 2004. Reproductive biology and diet of Liophis poecilogyrus poecilogyrus (Serpentes, Colubridae) from southeastern Brazil. Phyllomedusa 3(1): 9-14.

PIZZATTO, L., ALMEIDA-SANTOS, S.M. \& SHINE, R. 2007. Life-History adaptations to arboreality in snakes. Ecology 88(2): 359-366.

PONTES, G.M.F. 2007. História natural de Philodryas patagoniensis (Serpentes: Colubridae) no litoral do Rio Grande do Sul, Brasil. Tese de doutorado, Pontifícia Universidade Católica do Rio Grande do Sul, Rio Grande do Sul.

POUGH, F.H. \& GROVES, J.D. 1983. Specializations of the body form and food habits of snakes. Am. Zool. 23(2): 443-454.

RIVAS, J.A. \& BURGHARDT, G.M. 2001. Understanding sexual size dimorphism in snakes: wearing the snake's shoes. Anim. Behav. 62(5): F1-F6

SHETTY, S. \& SHINE, R. 2002. Sexual divergence in diets and morphology in Fijian sea snakes Laticauda colubrina (Laticaudinae). Austral Ecol. 27(1): 77-84.

SHINE, R. 1978. Sexual size dimorphism and male combat in snakes. Oecologia 33(3): 269-277.

SHINE, R. 1986. Sexual differences in morphology and niche utilization in an aquatic snake, Acrochordus arafurae. Oecologia 69(2): 260-267.

SHINE, R. 1991. Intersexual dietary divergence and the evolution of sexual dimorphism in snakes. Am. Nat. 138(1): 103-122.

SHINE, R. 1993. Sexual dimorphism in snakes. In Snakes-Ecology and Behavio (R.A. SEIGE, \& J.T. COLLINS eds.). McGraw-Hill Inc, New York p.49-86.

SHINE, R. 1994. Sexual Size Dimorphism in Snakes Revisited. Copeia 1994(2): 326-346.

SHINE, R. 2000. Vertebral numbers in male and female snakes: the roles of natural, sexual and fecundity selection. J. Evol. Biol. 13(2000): 455-465.

SOLORZANO, A. \& CERDAS, L. 1989. Reproductive Biology and Distribution of the Terciopelo, Bothrops asper Garman (Serpentes: Viperidae), in Costa Rica. Herpetologica 45(4): 444-450.

THOMAS, R.A. 1976. A revision of the American colubrid snake genus Philodryas Wagler, 1830. Thesis, Graduate College of Texas A \& M University, Texas.

VANZOLINI, P.E. \& BRANDÃO, J.H.F. 1944/45. Notas sobre algumas diferenças sexuais na folidose de Bothrops alternata D. \& B. 1854, e sua variação geográfica. Mem. Inst. Butantan 18: 251-258.

VINCENT, S.E., HERREL, A. \& IRSCHICK, D.J. 2004. Ontogeny of intersexual head shape and prey selection in the pitviper Agkistrodon piscivorus. Biol. J. Linn. Soc. 81 (1), 151-159.

YUKI, V.L.F. 1994. Revisão de Xenodon Boie, 1826 e Waglerophis Romano et Hoge, 1973 (Serpentes, Colubridae, Xenodontinae, Xenodontini). Tese de doutorado, Pontifícia Universidade Católica do Rio Grande do Sul, Rio Grande do Sul.

ZAHER, H., SCROCCHI, G \& MASIERO, R. 2008. Rediscovery and redescription of the type of Philodryas laticeps Werner, 1900 and the taxonomic status of P. oligolepis Gomes, 1921 (Serpentes, Colubridae). Zootaxa 1940(2008): 25-40.

ZUG, G.R., VITT, L.J. \& CALDWELL, J.P. 2001. Herpetology. An Introductory Biology of Amphibians and Reptiles. 2 ed. Academic Press, San Diego.

Received: 10/08/2016

Revised: $18 / 01 / 2017$

Accepted: 23/02/2017

Published online: $27 / 03 / 2017$

\section{Appendix}

Localities of collection of specimens analyzed, and respectives codes of voucher specimens at the zoological collection of reference.

Bahia: Caravelas (MNRJ 9336), Cocos (CHUNB 51369; CHUNB 51370; CHUNB 51371; CHUNB 51372; CHUNB 51373), Sem procedência (MUZUSP 10082). Brasília: Brasília (CHUNB 139; CHUNB 3620; CHUNB 3640; CHUNB 3773; CHUNB 3774; CHUNB 3775; CHUNB 3776; CHUNB 3777; CHUNB 3778; CHUNB 3779; CHUNB 3781; CHUNB 3783; CHUNB 3784; CHUNB 3785; CHUNB 3787; CHUNB 3788; CHUNB 3789; CHUNB 3790; CHUNB 3837; CHUNB 14181; CHUNB 18473; CHUNB 19328; CHUNB 19330; CHUNB 19334; CHUNB 19337; CHUNB 19339; CHUNB 19340; CHUNB 19341; CHUNB 24445; CHUNB 24563; CHUNB 24596; CHUNB 25355; CHUNB 28948; CHUNB 30380; CHUNB 30843; CHUNB 40793; CHUNB 44139; CHUNB 49608; CHUNB 50788; CHUNB 56858; CHUNB 56862; CHUNB 56880; CHUNB 57464; CHUNB 65799). Espírito Santo: Guarapari (MNRJ 20045), Piúma (MCNR 2611). Goiás: Alto Paraíso de Goiás (MNRJ 9351; CHUNB 3751; CHUNB 19331; CHUNB 19342; CHUNB 59128; CHUNB 59129; CHUNB 59131; CHUNB 59132; CHUNB 59523), Catalão (MNRJ 7440), Cristalina (CHUNB 19335), Colinas do Sul (MNRJ 21197), Formosa (CHUNB 27640), Mineiros (CHUNB 18440; CHUNB 23729), Minaçu (CHUNB 3768), Planaltina de Goiás (CHUNB 19332), Rio Verde (CHUNB 50288), Teresinha de Goiás (MCNR 3187), Sem procedência (MUZUSP 1908; MUZUSP 15047; MUZUSP 17773). Mato Grosso: Chapada dos Guimarães (CHUNB 20421), Corumbá (MNRJ 20943; MNRJ 20994). Maranhão: Perdizes (MNRJ 11342). Mato Grosso do Sul: Miranda (FUNED 1942). Minas Gerais: Belo Horizonte (FUNED 973, MNRJ 4849), Bom Despacho (FUNED 195), Cachoeira Escuro (FUNED 2206), Caxambú (UFJF 17), Chácara (UFJF 875; UFJF 883), Conceição do Mato dentro (FUNED 1637; FUNED 1695), Contagem (MCNR 81), Cordisburgo (FUNED 198), Coromandel (MNRJ 8405; MNRJ 8406), Ingaí (UNILAVRAS 157; UNILAVRAS 216; UNILAVRAS 241), Irapé (MCNR 1707; MCNR 2913), Itabirito (LZV 94), Itaperuna (FUNED 1913), Jaboticatubas (MNRJ 8879), Jaíba (FUNED 1466), Juiz de Fora (UFJF78; UFJF79; UFJF500), Km 813, sentido Juiz de Fora, BR-040, RJ (MNRJ 19878), Lagoa Santa (MNRJ 1323), Liberdade (MNRJ 8408), Mariana (MUZUSP 15726; MUZUSP 15727; FUNED 1142), Mina do Serro (MCNR 3390), Nova Lima (LZV 177), Nova Ponte (FUNED 725; FUNED 772; FUNED 774; FUNED 775), Ouro Branco (LZV 285; LZV 493), Ouro Preto (LZV 16; LZV 17; LZV 18; LZV 36; LZV 61; LZV 62; LZV 69; LZV 93; LZV 148; LZV 161; LZV 162; LZV 172; LZV 250; LZV 262; LZV 273; LZV 286; LZV 287; LZV 293; LZV 294; LZV 327; LZV 357; LZV 358; LZV 391; LZV 424; LZV 442; LZV 443; LZV 454; LZV 455; LZV 481; LZV 596; LZV 654; LZV 666; LZV 670; LZV 671; LZV 736; LZV 773; LZV 787; LZV 807; LZV 886; LZV 902; LZV 989; MUZUSP 14096; MUZUSP 14212; MUZUSP 15149), Paracatu (MCNR 3158), Pedro Leopoldo (MCNR 95), Poços de Caldas (MNRJ 4511, MUZUSP 14072; MUZUSP 14093), Queimados, entre os municípios de Cabeira Grande - MG, Unaí - MG, Cristalina GO (MNRJ 10930), Rio novo (MNRJ 9584), Rio Preto (MCNR 4338), Sacramento (MZUFV 1077), Santa Bárbara do Monte Verde (MNRJ 7068), São Gonçalo do Rio abaixo (MNRJ 9047), São Roque de Minas (MZUFV 1755; MZUFV 1761; MZUFV 1826), São Simão (MNRJ 4919), Serra do Cipó (MCNR 3530), Tocantins (MZUFV 1369), Transição ente Paracatu e Pirapora (MCNR 3286), Unaí (CHUNB 3618; CHUNB 24389; CHUNB 24477; CHUNB 29420), Varginha (MUZUSP 15155), Viçosa (MZUFV 62; MZUFV 155; MZUFV 336; MZUFV 719; MZUFV 1149; MZUFV 1203; MZUFV 1611; MZUFV 1615), Sem procedência (MUZUSP 15732; MUZUSP 17984; MUZUSP 17991; MUZUSP 18656). Pará: Santarém 
(CHUNB 6665). Paraíba: João Pessoa (MUZUSP 8267; MUZUSP 8999; MNRJ 9717). Paraná: Curitiba (MUZUSP 3685; MUZUSP 3686), Ponta Grossa (MUZUSP 5787), São Jerônimo da Serra (MUZUSP 11520), São José dos Pinhais (MUZUSP 13868). Pernambuco: Sem procedência (MNRJ 620; MUZUSP 975). Rio de Janeiro: Arraial do Cabo (MNRJ 21774; MNRJ 21775; MNRJ 22924), Barra de São João (MNRJ 7684; MNRJ 8376), Búzios (MNRJ 10182), Cabo Frio (MUZUSP 4203; MUZUSP 5870; MUZUSP 10802; MNRJ 8401; MNRJ 8373), Cachoeira do Macacu (MNRJ 12350; MNRJ 12351; MNRJ 20923), Campos dos Goytacazes (MNRJ 16400; MNRJ 17765), Conceição de Macabu (MNRJ 16438), Guapimirim (MNRJ 14303), Iguaba (MNRJ 8403), Iguaba Grande (MNRJ 17340; MNRJ 17926; MNRJ 18128; MNRJ 18129; MNRJ 18130; MNRJ 18521), Macaé (MUZUSP 7486; MNRJ 15660; MNRJ 19240), Magé (MNRJ 16470), Maricá (MNRJ 4739; MNRJ 8402; MNRJ 13165, MNRJ 13166; MNRJ 14087), Nova Iguaçu (MNRJ 21776), Niterói (MNRJ 8359), Paulo Frantin (MNRJ 8377), Piraí (MNRJ 8375), São João da Barra (MNRJ 17436), Saquarema (MNRJ 7269; MNRJ 14122), Silva Jardim (MNRJ 19861), Sem procedência (MUZUSP 2338; MNRJ 3992). Rio Grande do Sul: Itaqui (MUZUSP 1385; MUZUSP 1852), Jaquirana (CHUNB 49965), Porto 15 de Novembro (MUZUSP 11604; MUZUSP 11605), São Lourenço (MUZUSP 248; MUZUSP 250), Taím (MUZUSP 7435), Tupaceretan (MUZUSP 2576), Viamão (MUZUSP 5745), Sem procedência (MUZUSP 270; MUZUSP 7335). Roraima: Boa Vista (CHUNB 6650). Santa Catarina: Palhoça (MNRJ 20169; MNRJ 20172; MNRJ 20173), Sem procedência (MUZUSP 5182; MUZUSP 9425; MUZUSP 9426).
São Paulo: Anhembi (MNRJ 21753), Atibaia (MUZUSP 245), Botucatu (MUZUSP 2426; MUZUSP 2644; MUZUSP 2645; MUZUSP 3458; MNRJ 18545; MNRJ 18546; MNRJ 19336; MNRJ 20480; MNRJ 21131; MNRJ 21745; MNRJ 21748; MNRJ 21751; MNRJ 21908; MNRJ 21919; MNRJ 22079; MNRJ 22136; MNRJ 22140; MNRJ 22142; MNRJ 22143; MNRJ 22144; MNRJ 22147; MNRJ 22841; MNRJ 22903; MNRJ 22904; MNRJ 22905; MNRJ 22906; MNRJ 22907), Campinas (MUZUSP 244), Cotia (CHUNB 6124), Divisa do Campos dos Goytacazes - SP e Mimoso do Sul -ES (MNRJ 15817; MNRJ 15847), Jundiaí (MUZUSP 12810; MNRJ 17120), Juquitiba (MUZUSP 16495), Mogi das Cruzes (CHUNB 24490), Pedreira (CHUNB 6123), São Bernardo do Campo (MUZUSP 4024), São Vicente (MUZUSP 4572), Serra da Bocaina (MUZUSP 4103; MUZUSP 4649; MUZUSP 4911), Sem procedência (MUZUSP 239; MUZUSP 1689; MUZUSP 1955; MUZUSP 2640; MUZUSP 2860; MUZUSP 2861; MUZUSP 2979; MUZUSP 3457; MUZUSP 4068; MUZUSP 4069; MUZUSP 4605; MUZUSP 4651; MUZUSP 5519; MUZUSP 8531; MUZUSP 12355; MUZUSP 12832; MUZUSP 16529). Sergipe: Itabaiana (MUZUSP 15840), São Cristovão (MUZUSP 15838; MUZUSP 15839), Sem procedência (MUZUSP 17454; MUZUSP 17455). Tocantins: Figueirópolis (CHUNB 62806), Guaraí (MUZUSP 1269), Mateiros (CHUNB 33800; CHUNB 41108, CHUNB 41109; CHUNB 41110; CHUNB 41111), Paraná (CHUNB 38287), Pedro Afonso (CHUNB 52431), Sem procedência (MUZUSP 14396; MUZUSP 14601; MUZUSP 15508; MUZUSP 15509; MUZUSP 15510; MUZUSP 15511). 